\title{
Cadmium-induced oxidative damage in rice leaves is reduced by polyamines
}

\author{
Yi Ting Hsu · Ching Huei Kao
}

Received: 12 June 2006/ Accepted: 23 November 2006/Published online: 19 January 2007

(C) Springer Science+Business Media B.V. 2007

\begin{abstract}
The protective effect of polyamines against $\mathrm{Cd}$ toxicity of rice (Oryza sativa) leaves was investigated. $\mathrm{Cd}$ toxicity to rice leaves was determined by the decrease in protein content. $\mathrm{CdCl}_{2}$ treatment results in (1) increased $\mathrm{Cd}$ content, (2) induction of Cd toxicity, (3) increase in $\mathrm{H}_{2} \mathrm{O}_{2}$ and malondialdehyde (MDA) contents, (4) decrease in ascorbic acid (ASC) and reduced glutathione (GSH) contents, and (5) increase in the activities of antioxidative enzymes (superoxide dismutase, glutathione reductase, ascorbate peroxidase, catalase, and peroxidase). Spermidine (Spd) and spermine (Spm), but not putrescine (Put), were effective in reducing $\mathrm{CdCl}_{2}$-induced toxicity. Spd and Spm prevented $\mathrm{CdCl}_{2}$-induced increase in the contents of $\mathrm{H}_{2} \mathrm{O}_{2}$ and MDA, decrease in the contents of ASC and GSH, and increase in the activities of antioxidative enzymes. Spd and Spm pretreatments resulted in a decrease in $\mathrm{Cd}$ content when compared with $\mathrm{H}_{2} \mathrm{O}$ pretreatment, indicating that Spd and Spm may reduce the uptake of Cd. Results of the present study suggest that $\mathrm{Spd}$ and $\mathrm{Spm}$ are able to protect $\mathrm{Cd}$-induced oxidative damage and this protection is most likely related to the avoidance of $\mathrm{H}_{2} \mathrm{O}_{2}$ generation and the reduction of $\mathrm{Cd}$ uptake.
\end{abstract}

\section{Y. T. Hsu · C. H. Kao ( $ه)$}

Department of Agronomy, National Taiwan University, Taipei, Taiwan, Republic of China

e-mail:kaoch@ntu.edu.tw
Keywords Cadmium - Oxidative stress . Putrescine $\cdot$ Rice $\cdot$ Spermidine Spermine
Abbreviations
APX Ascorbate peroxidase
ASC Ascorbic aicd
CAT Catalase
DAB 3,3'-Diaminobenzidine
DHA Dehydroascorbate
DW Dry weight
FW Fresh weight
GR Glutathione reductase
GSH Reduced glutathione
GSSG Oxidized glutathione
POX Peroxidase
Put Putrescine
ROS Reactive oxygen species
SOD Superoxide dismutase
Spd Spermidine
Spm Spermine

\section{Introduction}

Cadmium (Cd), a heavy metal toxic to humans, animals, and plants, is a widespread pollutant with a long biological half-life (Wagner 1993). Cd is readily taken up by plants, leading to toxic symptoms such as growth reduction (Chen and 
Kao 1995). Cd damages the photosynthetic apparatus (Krupa 1988; Siedlecka and Baszynski 1993), lowers chlorophyll (Stobart et al. 1985; Larsson et al. 1998), and alters proline and polyamine contents (Sharma and Dietz 2006).

Oxygen is essential for the existence of aerobic life, but toxic reactive oxygen species (ROS), which include the superoxide anion $\mathrm{O}_{2}^{-}$, hydroxyl radical $(\mathrm{OH} \bullet)$ and hydrogen peroxide $\left(\mathrm{H}_{2} \mathrm{O}_{2}\right)$, are generated in all aerobic cells during metabolic processes (Asada 1999; Foyer et al. 1994, 1997). Initially, ROS were only regarded as damaging to cells (Apel and Hirt 2004). More recently, ROS emerged as ubiquitous signaling molecules participating in the recognition of and the response to stress factors (Foyer and Noctor 2005).

Injury caused by these ROS, known as oxidative stress, is one of the major damaging factors in plants exposed to environmental stress. Plants cope with oxidative stress by using antioxidative enzymes such as superoxide dismutase (SOD), ascorbate peroxidase (APX), glutathione reductase (GR), peroxidase (POX), catalase (CAT), and the low molecular weight antioxidants, ascorbic acid (ASC) and glutathione (GSH) (Asada 1999; Noctor and Foyer 1998). Three lines of evidence indicate that one mechanism of $\mathrm{Cd}$ toxicity is related to oxidative stress in plant cells. First, Cd can promote the generation of ROS (Kuo and Kao 2004; Olmos et al. 2003; Piqueras et al. 1999; Romero-Puertas et al. 2003, 2004; Sandalio et al. 2001; Schützendübel et al. 2001; Shah et al. 2001). Second, Cd can inhibit or stimulate the activities of antioxidant enzymes (Chaoui et al. 1997; Dixit et al. 2001; Gallego et al. 1996; Innelli et al. 2002; Kuo and Kao 2004; León et al. 2002; Shah et al. 2001; Shaw 1995). Third, treatment with $\mathrm{Cd}$ results in cellular oxidative damage or lipid peroxidation (Chaoui et al. 1997; Chien et al. 2002; Dixit et al. 2001; Gallego et al. 1996; Kuo and Kao 2004; LozanoRodríguez et al. 1997; Shah et al. 2001; Shaw 1995).

The polyamines putrescine (Put), spermidine (Spd), and spermine (Spm) are polycationic cellular molecules and are present in all living organisms. Experimental evidence now indicates that polyamines are involved in a number of cellular and molecular processes in plants
(Bouchereau et al. 1999; Wallace et al. 2003). The levels of polyamines in plants are altered in response to heavy metals (Sharma and Dietz 2006). Weinstein et al. (1986) showed an up to 10fold increase in Put content with a marginal rise in Spd and Spm contents in Cd-treated oat seedlings and detached oat leaves. Similar results were obtained in Cd-treated detached rice leaves (Hou and Kao 1993). It has been shown that polyamines are able to protect against oxidative damage caused by paraquat (Benavides et al. 2000; Chang and Kao 1997; Kurepa et al. 1998; Minton et al. 1990), acid rain (Velikova et al. 2000) and heavy metals such as $\mathrm{Cd}$ and $\mathrm{Cu}$ (Groppa et al. 2001). Borrell et al. (1997) demonstrated that polyamines inhibited lipid peroxidation in senescing oat leaves. Evidence has been provided to show that polyamines are effective radical scavengers in a number of chemical and in vitro enzyme systems (Drolet et al. 1986) and that the reduction in polyamine content in leaves of Glycyrrhiza inflata under osmotic stress promoted the increase in the production of ROS (Li and Wang 2004). A close interrelationship between polyamines and oxidative stress was documented by the finding that leaf necrosis caused by ozone in tomato plants could be suppressed by an exogenous supply of polyamines (Ormrod and Beckerson 1986). However, Bors et al. (1989) claimed that the scavenging of radicals by polyamines cannot explain the protection against ozone damage observed after exogenous application. Recently, Tang et al. (2004) demonstrated that exogenously added polyamines recover browning tissues into normal callus cultures of Virginia pine by decreasing oxidative damage. In the present study, we investigated the effect of polyamines on $\mathrm{Cd}$ toxicity of rice leaves, and we observed that oxidative damage caused by $\mathrm{CdCl}_{2}$ is reduced by Spd and Spm.

\section{Materials and methods}

\section{Plant material}

Rice (Oryza sativa L., cv. Taichung Native 1) seeds were sterilized with $2.5 \%$ sodium hypochlorite for $15 \mathrm{~min}$ and washed extensively seeds with 
distilled water. These seeds were then germinated in Petri dishes with wetted filter paper at $37^{\circ} \mathrm{C}$ under dark conditions. After $48 \mathrm{~h}$ incubation, uniformly germinated seeds were selected and cultivated in a $500 \mathrm{ml}$ beaker containing halfstrength Kimura B solution as described previously (Hsu and Kao 2005). The hydroponically cultivated seedlings were grown for 12 days in a Phytotron (Agricultural Experimental station, National Taiwan University, Taipei, Taiwan) with natural sunlight at $30^{\circ} \mathrm{C}$ day $/ 25^{\circ} \mathrm{C}$ night and $90 \%$ relative humidity. The apical $3 \mathrm{~cm}$ of the third leaf was used in all experiments. Detached rice leaves were pretreated with distilled water or polyamines for $6 \mathrm{~h}$ at $27^{\circ} \mathrm{C}$ in darkness and then transferred to distilled water or $5 \mathrm{mM} \mathrm{CdCl}_{2}$ for $4,8,12$, and $18 \mathrm{~h}$ at $27^{\circ} \mathrm{C}$ in the light $\left(40 \mu \mathrm{mol} \mathrm{m} \mathrm{m}^{-2}\right)$.

Determination of protein, $\mathrm{H}_{2} \mathrm{O}_{2}$, lipid peroxidation, GSH, oxidized glutathione (GSSG), ASC, dehydroascorbate (DHA), and $\mathrm{Cd}$

For protein determination, leaf segments were homogenized in a $50 \mathrm{mM}$ sodium phosphate buffer ( $\mathrm{pH}$ 6.8). The extracts were centrifuged at $17,600 \times g$ for $20 \mathrm{~min}$, and the supernatants were used for determination of protein by the method of Bradford (1976) and antioxidative enzyme activities. The $\mathrm{H}_{2} \mathrm{O}_{2}$ content was measured colorimetrically as described by Jana and Choudhuri (1982). $\mathrm{H}_{2} \mathrm{O}_{2}$ was extracted by homogenizing leaf tissue with phosphate buffer $(50 \mathrm{mM}$, $\mathrm{pH}$ 6.5) containing $1 \mathrm{mM}$ hydroxylamine. The homogenate was centrifuged at $6,000 \times g$ for 25 min. To determine $\mathrm{H}_{2} \mathrm{O}_{2}$ content, the extracted solution was mixed with $0.1 \%$ titanium chloride in $20 \%(\mathrm{v} / \mathrm{v}) \mathrm{H}_{2} \mathrm{SO}_{4}$. The mixture was then centrifuged at $6,000 \times g$ for $15 \mathrm{~min}$. The absorbance was measured at $410 \mathrm{~nm}$. Using this method, we obtained that absorbance increased linearly with the amount of $\mathrm{H}_{2} \mathrm{O}_{2}$ and addition of $\mathrm{H}_{2} \mathrm{O}_{2}$ to leaf extracts resulted in the predicted increase of absorbance, i.e. added $\mathrm{H}_{2} \mathrm{O}_{2}$ was fully recovered (data not shown). The $\mathrm{H}_{2} \mathrm{O}_{2}$ content in leaf extracts was calculated using the extinction coefficient of $0.28 \mu \mathrm{mol}^{-1} \mathrm{~cm}^{-1}$. In some experiments, $\mathrm{H}_{2} \mathrm{O}_{2}$ was also visually detected in the leaves by using 3,3-diaminobenzidine (DAB) as substrate (Orozco-Cárdenas and Ryan 1999). Detached rice leaves were supplied through the cut ends with DAB $\left(1 \mathrm{mg} \mathrm{ml}^{-1}\right)$ solution for $24 \mathrm{~h}$ under light at $27^{\circ} \mathrm{C}$. Leaves were them decolorized in boiling ethanol (95\%) for $0.5 \mathrm{~h}$. This treatment decolorized the leaves except for the brown polymerization product produced by $\mathrm{DAB}$ with $\mathrm{H}_{2} \mathrm{O}_{2}$. After cooling, the leaves were extracted at room temperature with fresh ethanol. The $\mathrm{H}_{2} \mathrm{O}_{2}$ staining was repeated four times with similar results.

MDA, routinely used as an indicator of lipid peroxidation, was extracted with $5 \%(\mathrm{w} / \mathrm{v})$ trichloroacetic acid and determined by the thioburbituric acid reaction as described by Heath and Packer (1968). GSH and GSSG in 3\% sulfosalicylic acid extract and ASC and DHA in 5\% (w/v) trichloracetic acid extract were determined as described previously (Hsu and Kao 2005). For determination of $\mathrm{Cd}$, leaves were dried at $65^{\circ} \mathrm{C}$ for $48 \mathrm{~h}$ and the dried material ashed at $550^{\circ} \mathrm{C}$ for 4 days. The ash residue was incubated with $31 \%$ $\mathrm{HNO}_{3}$ and $17.5 \% \mathrm{H}_{2} \mathrm{O}_{2}$ at $72^{\circ} \mathrm{C}$ for $2 \mathrm{~h}$, and dissolved in distilled water. $\mathrm{Cd}$ was then quantified using an atomic absorption spectrophotometer (Model AA-6800, Shimadzu, Kyoto, Japan).

Polyamine determination

Leaf tissues were homogenized with $5 \mathrm{ml}$ of $5 \%$ $(\mathrm{w} / \mathrm{v})$ perchloric acid. Polyamine contents were determined using high performance liquid chromatography (Waters 484, Milford, USA) after benzoylation as described previously (Chen and Kao 1991).

Enzyme extraction and assays

For extraction of enzymes, leaf tissues were homogenized with $0.1 \mathrm{M}$ sodium phosphate buffer (pH 6.8) in a chilled pestle and mortar. For analysis of APX activity, $2 \mathrm{mM}$ ASC was added to the extraction buffer. The homogenate was centrifuged at $12,000 \times g$ for $20 \mathrm{~min}$ and the resulting supernatant was used for determination of enzyme activity. The whole extraction procedure was carried out at $4{ }^{\circ} \mathrm{C}$. SOD was determined according to Paoletti et al. (1986). One unit of SOD was defined as the amount of enzyme that 
inhibits by $50 \%$ the rate of NADH oxidation observed in blank sample. POX activity was measured using a modification of the procedure of MacAdam et al. (1992). The activity was calculated using the extinction coefficient $\left(26.2 \mathrm{mM}^{-1} \mathrm{~cm}^{-1}\right.$ at $\left.470 \mathrm{~nm}\right)$ for tetraguaiacol. One unit of POX was defined as the amount of enzyme that caused the formation of $1 \mu \mathrm{mol}$ tetraguaiacol per min. CAT activity was assayed according to Kato and Shimizu (1987). One unit of CAT was defined as the amount of enzyme which degraded $1 \mu$ mol $\mathrm{H}_{2} \mathrm{O}_{2}$ per min. APX activity was determined according to Nakano and Asda (1981). One unit of activity for APX was defined as the amount of enzyme that degraded $1 \mu \mathrm{mol}$ of ASC per min. GR was determined by the method of Foster and Hess (1980). One unit of GR was defined as the amount of enzyme that decreased $1 \mathrm{~A}_{340}$ per min.

\section{Statistical analysis}

Statistical differences between measurements $(n=4)$ on different treatments or on different times were analyzed following the Duncan's multiple range test or Student's t-test.

\section{Results}

\section{Cd promotes protein loss}

In plants, the most general symptom of $\mathrm{Cd}$ toxicity is chlorosis (Das et al. 1997). In rice, we have shown that detached leaves and seedlings treated with $\mathrm{CdCl}_{2}$ show chlorosis and protein loss (Chien and Kao 2000; Hsu and Kao 2003, 2005). In the present study, Cd toxicity in detached rice leaves caused by excess $\mathrm{Cd}$ was assessed by a decrease in protein content. Increasing concentration of $\mathrm{CdCl}_{2}$ from 0.1 to $5 \mathrm{mM}$ progressively decreased protein content in detached rice leaves in the light and no further decrease was observed at $10 \mathrm{mM} \mathrm{CdCl}_{2}$ (data not shown). Thus, $5 \mathrm{mM} \mathrm{CdCl} 2$ was used in the present investigation. The promotion of the loss of protein by $\mathrm{CdCl}_{2}$ was evident $8 \mathrm{~h}$ after treatment (Fig. 1A). Cd concentration in the control leaves remained unchanged during $18 \mathrm{~h}$ of incu- bation (Fig. 1C). However, Cd concentration in $\mathrm{CdCl}_{2}$-treated leaves increased with increasing duration of incubation (Fig. 1C). The increase in $\mathrm{Cd}$ concentration in $\mathrm{CdCl}_{2}$-treated leaves was evident $4 \mathrm{~h}$ after treatment (Fig. 1C).

Cd induces oxidative stress

MDA content in $\mathrm{CdCl}_{2}$-treated detached rice leaves was observed to be greater than that in water-treated controls at $8 \mathrm{~h}$ after treatment (Fig. 1B). This showed that $\mathrm{Cd}$ toxicity in detached rice leaves was linked to lipid peroxidation. Lipid peroxidation is caused by ROS (Thompson et al. 1987). $\mathrm{CdCl}_{2}$ treatment also
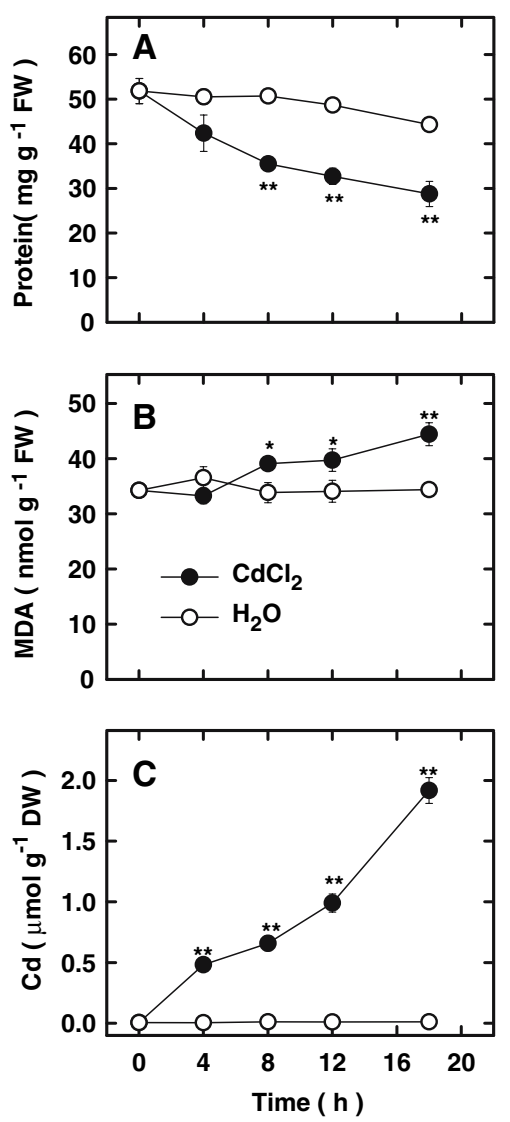

Fig. 1 Changes in the contents of protein (A), MDA (B), and $\mathrm{Cd}(\mathrm{C})$ in rice leaves treated with $\mathrm{CdCl}_{2}$. Detached rice leaves were pretreated with $\mathrm{H}_{2} \mathrm{O}$ for $6 \mathrm{~h}$ in the dark and then treated with $\mathrm{H}_{2} \mathrm{O}$ or $5 \mathrm{mM} \mathrm{CdCl}_{2}$ for $4,8,12$, and $18 \mathrm{~h}$ in the light. $*$ and $* *$ represent values that are significantly different between $\mathrm{H}_{2} \mathrm{O}$ and $\mathrm{CdCl}_{2}$ treatment at $P<0.05$ and $P<0.01$, respectively 
Fig. 2 Changes in the contents of $\mathrm{H}_{2} \mathrm{O}_{2}$ (A) and the activities of SOD (B), GR (C), APX (D), CAT $(\mathrm{E})$, and $\mathrm{POX}(\mathrm{F})$ in rice leaves treated with $\mathrm{CdCl}_{2}$. Detached rice leaves were pretreated with $\mathrm{H}_{2} \mathrm{O}$ for $6 \mathrm{~h}$ in the dark and then treated with $\mathrm{H}_{2} \mathrm{O}$ or $5 \mathrm{mM} \mathrm{CdCl}_{2}$ for $4,8,12$, and $18 \mathrm{~h}$ in the light.

$*$ and ** represent values that are significantly different between $\mathrm{H}_{2} \mathrm{O}$ and $\mathrm{CdCl}_{2}$ treatment at $P<0.05$ and $P<0.01$, respectively
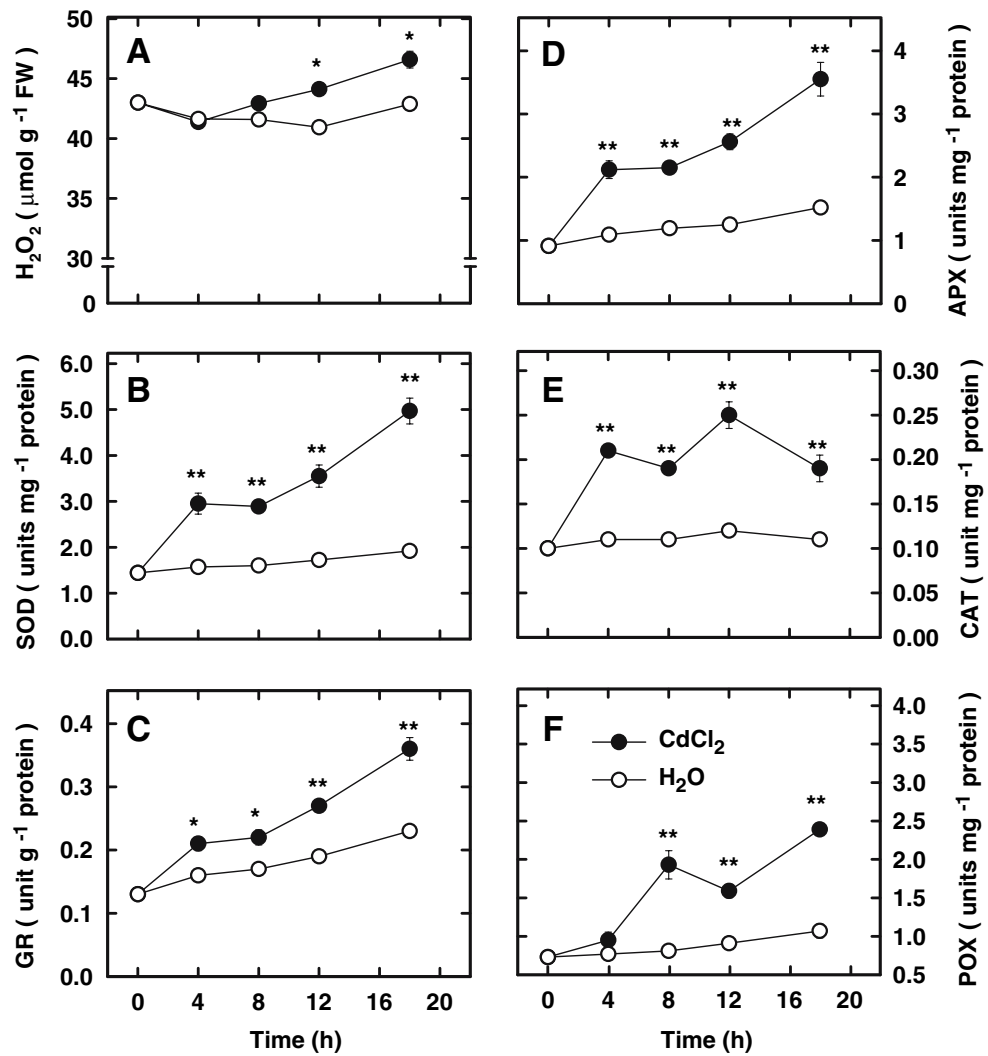

caused an increase in $\mathrm{H}_{2} \mathrm{O}_{2}$ content (Fig. 2A). To verify in situ the increase in $\mathrm{H}_{2} \mathrm{O}_{2}$ in leaves treated with $\mathrm{CdCl}_{2}$, a histochemical method with $\mathrm{DAB}$ that is based on the formation by $\mathrm{H}_{2} \mathrm{O}_{2}$ of brown polymerization product was used. The development of $\mathrm{DAB}-\mathrm{H}_{2} \mathrm{O}_{2}$ reaction product in $\mathrm{H}_{2} \mathrm{O}$ - and $\mathrm{CdCl}_{2}$-treated leaves is shown in Fig. 3 . It is clear that the DAB- $\mathrm{H}_{2} \mathrm{O}_{2}$ reaction product was observed after $\mathrm{H}_{2} \mathrm{O}_{2}$ and $\mathrm{CdCl}_{2}$ treatments. All these results support the involvement of ROS as the chemical species inducing $\mathrm{Cd}$ toxicity in rice leaves.

$\mathrm{CdCl}_{2}$-treated rice leaves had higher activities of SOD, GR, APX, and CAT than the controls at $4 \mathrm{~h}$ after treatment (Figs. 2B-E). Higher activities of POX were observed at $8 \mathrm{~h}$ after treatment (Fig. 2F). GSH, GSSG, and ASC contents were observed to be lower than the controls at $4 \mathrm{~h}$ after treatment (Figs. 4A-C). However, DHA content in Cd-treated leaves was observed to be higher than the contents at $18 \mathrm{~h}$ after treatment (Fig. 4D). The increased activities of antioxidative enzymes

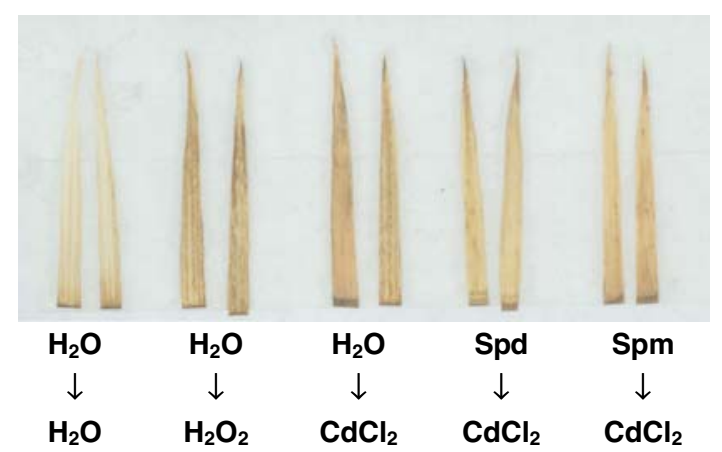

Fig. 3 Histochemical detection of $\mathrm{H}_{2} \mathrm{O}_{2}$ with $\mathrm{DAB}$ staining in rice leaves. Detached leaves were pretreated with $\mathrm{H}_{2} \mathrm{O}$, Spd, and Spm, respectively, for $6 \mathrm{~h}$ in the dark, and then treated with either $\mathrm{H}_{2} \mathrm{O}, \mathrm{H}_{2} \mathrm{O}_{2}$, or $\mathrm{CdCl}_{2}$ for $18 \mathrm{~h}$ in the light. The concentrations of Spd, Spm, $\mathrm{H}_{2} \mathrm{O}_{2}$, and $\mathrm{CdCl}_{2}$ were $5,5,1$, and $5 \mathrm{mM}$, respectively

and the decreased contents of ASC and GSH in response to $\mathrm{CdCl}_{2}$ are further suggestive of strong induction of oxidative stress. 
Fig. 4 Changes in contents of GSH (A) and ASC (B) in rice leaves treated with $\mathrm{CdCl}_{2}$. Detached rice leaves were pretreated with $\mathrm{H}_{2} \mathrm{O}$ for $6 \mathrm{~h}$ in the dark and then treated with $\mathrm{H}_{2} \mathrm{O}$ or $5 \mathrm{mM} \mathrm{CdCl}_{2}$ for $4,8,12$, and $18 \mathrm{~h}$ in the light. * and $* *$ represent values that are significantly different between $\mathrm{H}_{2} \mathrm{O}$ and $\mathrm{CdCl}_{2}$ treatment at $P<0.05$ and $P<0.01$, respectively
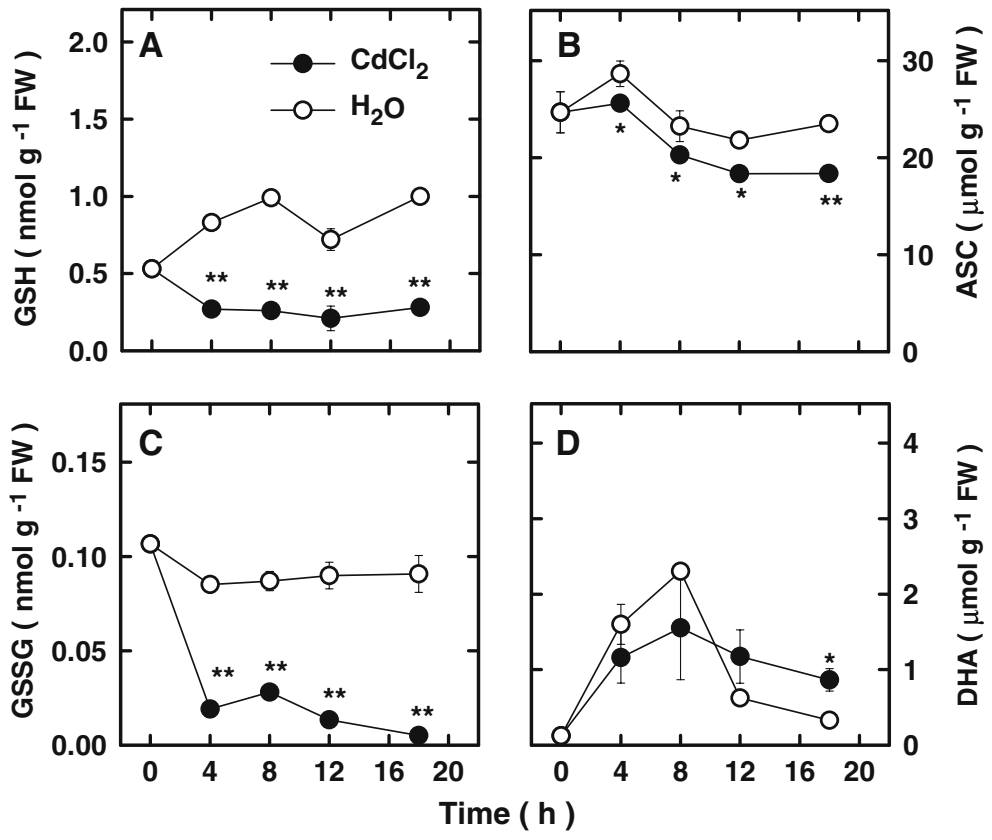

Spd and Spm reduce Cd-induced oxidative damage

To test if polyamines could reduce the toxicity caused by $\mathrm{CdCl}_{2}$, as judged by the changes in protein levels, detached rice leaves were pretreated with either water or polyamines for $6 \mathrm{~h}$ in the dark and then transferred to either water or $\mathrm{CdCl}_{2}$ for $18 \mathrm{~h}$ in the light. Spd and Spm, but not Put, pretreatments reduced Cd toxicity (Fig. 5). We also observed that $\mathrm{Spd}$ and $\mathrm{Spm}$ were effective in reducing Cd-induced lipid peroxidation (Fig. 6A) and $\mathrm{H}_{2} \mathrm{O}_{2}$ production (Figs. 3, 6B), Cd-increased antioxidative enzyme activities (Fig. 7), and $\mathrm{Cd}$ decreased ASC and GSH contents (Fig. 8). Furthermore, detached rice leaves pretreated with Spd or Spm for $6 \mathrm{~h}$ in the dark had higher endogenous levels of Spd and Spm, and Spm, respectively, than those pretreated with water (Table 1). However, Put pretreatment had no effect on endogenous levels of Spd and Spm (Table 1).

Spd and Spm inhibit the uptake of Cd

To test if endogenous Spd and Spm affect $\mathrm{Cd}$ uptake, $\mathrm{Cd}$ content in detached rice leaves pretreated with Spd or Spm followed by treatment of $\mathrm{CdCl}_{2}$ was determined. It was observed that $\mathrm{Spd}$

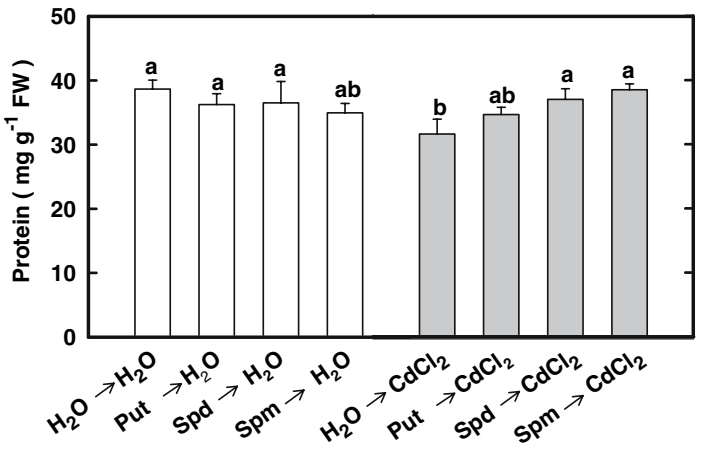

Fig. 5 Effect of pretreatments with polyamines on the content of protein in detached rice leaves in the presence or absence of $\mathrm{CdCl}_{2}$. Detached rice leaves were pretreated with $\mathrm{H}_{2} \mathrm{O}, 5 \mathrm{mM}$ Put, $5 \mathrm{mM} \mathrm{Spd}$, and $5 \mathrm{mM} \mathrm{Spm}$, respectively, for $6 \mathrm{~h}$ in the dark and then treated with $\mathrm{H}_{2} \mathrm{O}$ or $5 \mathrm{mM} \mathrm{CdCl}_{2}$ for $18 \mathrm{~h}$ in the light. Values with the same letter are not significantly different at $P<0.05$

and Spm pretreatments resulted in a decrease (about 27\%) in Cd content when compared with $\mathrm{H}_{2} \mathrm{O}$ pretreatment (Fig. 9).

\section{Discussion}

It has been shown that $\mathrm{Cd}$ increased ethylene production in detached rice leaves (Hou and Kao 1993). Here, we show that $\mathrm{Cd}$ induced $\mathrm{H}_{2} \mathrm{O}_{2}$ 

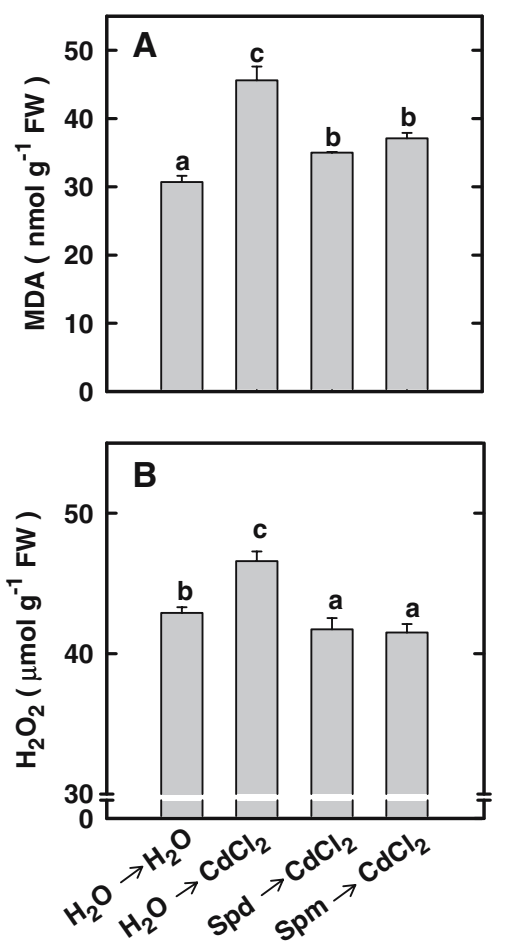

Fig. 6 Effect of pretreatments with Spd and Spm on the contents of MDA (A) and $\mathrm{H}_{2} \mathrm{O}_{2}$ (B) in detached rice leaves in the presence or absence of $\mathrm{CdCl}_{2}$. Detached rice leaves were pretreated with $\mathrm{H}_{2} \mathrm{O}, 5 \mathrm{mM}$ Spd, and $5 \mathrm{mM}$ $\mathrm{Spm}$, respectively, for $6 \mathrm{~h}$ in the dark and then treated with $\mathrm{H}_{2} \mathrm{O}$ or $5 \mathrm{mM} \mathrm{CdCl}_{2}$ for $18 \mathrm{~h}$ in the light. Values with the same letter are not significantly different at $P<0.05$

production in rice leaves (Fig. 2A, 3). Wounding is known to induce ethylene production ( $\mathrm{Yu}$ and Yang 1980) and $\mathrm{H}_{2} \mathrm{O}_{2}$ generation (Orozco-Cárdenas et al. 2001). Ethylene biosynthesis shares a common precursor with Spd and Spm, thus wounding may induce a direct modification of the synthesis of Spd and Spm. When detached rice leaves are used to study $\mathrm{H}_{2} \mathrm{O}_{2}$, ethylene, polyamines, and senescence, wounding is always a problem. However, in the present study, each long and narrow rice leaf was cut transversely; thus, the area of wounding was very small. Therefore, $\mathrm{H}_{2} \mathrm{O}_{2}$ and ethylene production of detached leaves induced by $\mathrm{Cd}$ is unlikely to be complicated by the wounding effect.

$\mathrm{Cd}$ is known to increase the production of $\mathrm{H}_{2} \mathrm{O}_{2}$ (Kuo and Kao 2004; Schützendübel et al. 2001; Olmos et al. 2003) and induce lipid peroxidation (Chien et al. 2002; Gallego et al. 1996; Kuo and Kao 2004). These results suggest that $\mathrm{Cd}$ treatment causes an oxidative stress in plants. Our results not only have shown that $\mathrm{CdCl}_{2}$ increased the content of $\mathrm{H}_{2} \mathrm{O}_{2}$ (Figs. 2A, 3) and the activities of SOD, APX, GR, CAT, and POX (Figs. 2B-F), but also demonstrated that caused a decrease in GSH and ASC contents (Fig. 4). Meanwhile, protein loss (Fig. 1A) and lipid peroxidation (Fig. 1B) were observed in $\mathrm{CdCl}_{2}$-treated rice leaves. All these results suggest that $\mathrm{CdCl}_{2}$ causes an oxidative stress and that $\mathrm{CdCl}_{2}$-induced toxicity in rice leaves is mediated through oxidative stress.

GSH functions as a direct antioxidant of ROS and is involved in the generation of ASC, which is utilized as a substrate for APX (Noctor and Foyer 1998). In the present study, we observed that the decrease in GSH content is one of the earliest steps in oxidative stress induced by $\mathrm{CdCl}_{2}$ in rice leaves, which occurred at $4 \mathrm{~h}$ after treatment (Fig. 4B). It may be suspected that the decrease in GSH may favor the accumulation of ROS in Cd-treated rice leaves. In a review, Schützendübel and Polle (2002) also suggest that the depletion of GSH is apparently a critical step in $\mathrm{Cd}$ toxicity.

$\mathrm{Cd}$ induced a significant accumulation of $\mathrm{H}_{2} \mathrm{O}_{2}$ in rice leaves (Figs. 2A, 3). Accumulation of $\mathrm{H}_{2} \mathrm{O}_{2}$ has also been observed in Cd-treated pine and pea roots, pea leaves, and tobacco cells (Olmos et al. 2003; Romero-Puertas et al. 2003; 2004; Schützendübel et al. 2001). There are reports showing that NADPH oxidase was possibly involved in Cd-induced $\mathrm{H}_{2} \mathrm{O}_{2}$ production in pea leaves and tobacco cells (Olmos et al. 2003; Romero-Puertas et al. 2004). Our unpublished observations indicate that diphenyleneiodonium chloride and imidazole, inhibitors of NADPH oxidase, prevented Cd-induced $\mathrm{H}_{2} \mathrm{O}_{2}$ production in rice leaves.

Data from the present study indicate that Cd-induced oxidative damage in rice leaves is reduced by Spd and Spm. This conclusion is based on the observations that pretreatment with Spd and Spm prevented Cd-induced loss of protein (Fig. 5), increase in the contents of MDA (Fig. 6) and $\mathrm{H}_{2} \mathrm{O}_{2}$ (Figs. 3, 6B), decrease in the content of ASC and GSH (Fig. 8), and increase in the 
Fig. 7 Effect of pretreatments with Spd and Spm on the activities of antioxidative enzymes [SOD (A), GR (B), APX (C), CAT (D), and POX (E) in detached rice leaves in the presence or absence of $\mathrm{CdCl}_{2}$.

Detached rice leaves were pretreated with $\mathrm{H}_{2} \mathrm{O}$, $5 \mathrm{mM}$ Spd, and $5 \mathrm{mM}$ Spm, respectively, for $6 \mathrm{~h}$ in the dark and then treated with $\mathrm{H}_{2} \mathrm{O}$ or $5 \mathrm{mM} \mathrm{CdCl}_{2}$ for $18 \mathrm{~h}$ in the light. Values with the same letter are not significantly different at $P<0.05$
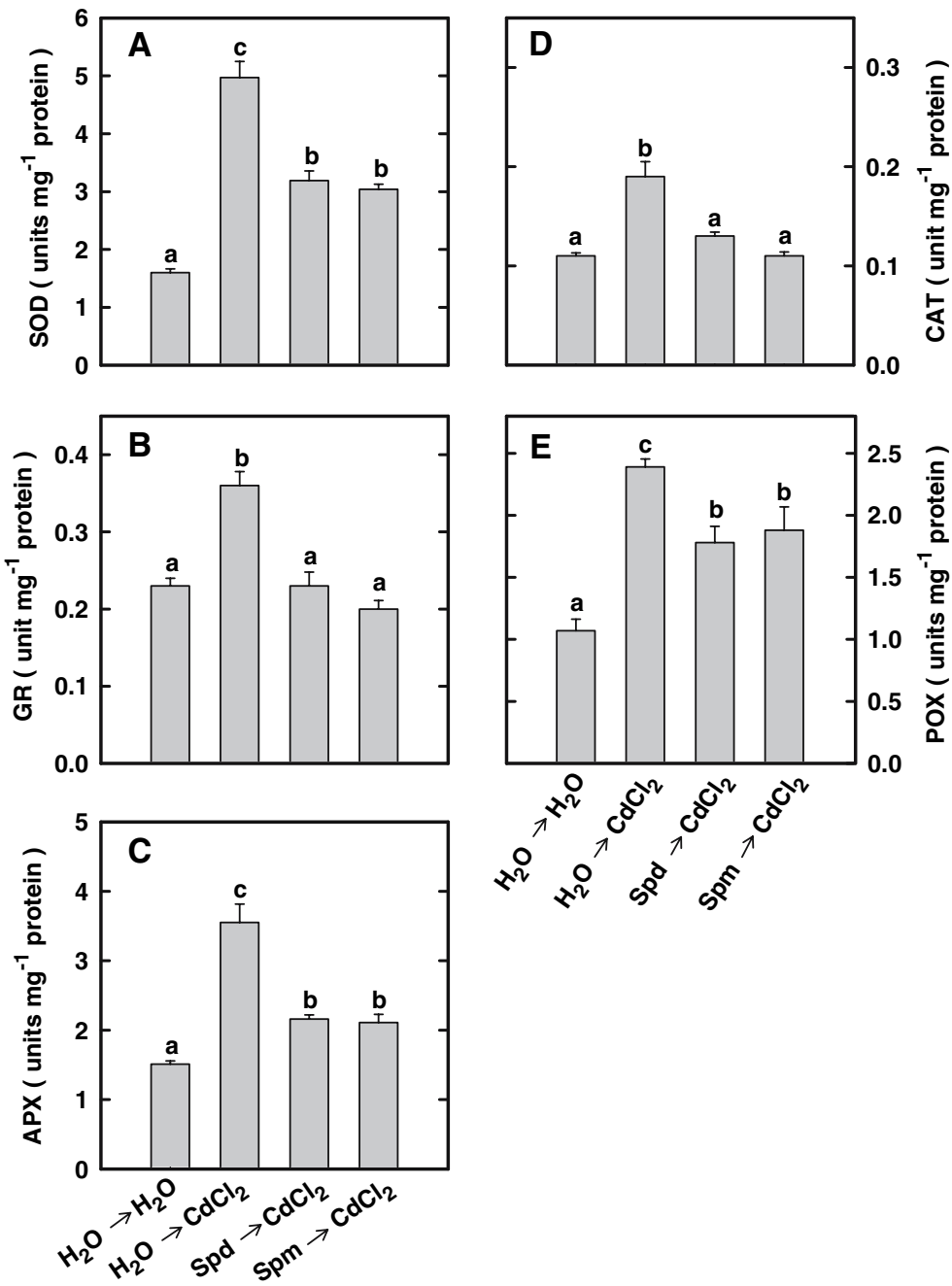

activities of antioxidative enzymes (Fig. 7). Groppa et al. (2001) also demonstrated that Spm and Spd were effective in reducing Cd-caused lipid peroxidation in sunflower leaf discs. It is generally accepted that polyamines are highly protonated at physiological $\mathrm{pH}$, which favors electrostatic binding of polyamines to negatively charged components of membranes, leading to membrane stabilization through ionic interactions (Slocum et al. 1984). The more pronounced protective effect of Spd and Spm could be accounted for by its longer chain and greater number of positive charges, which allows membrane stabilizing ability.

The decrease in ASC and GSH contents in rice leaves treated with $\mathrm{CdCl}_{2}$ suggests that ASC and
GSH contents may be regulated by the synthesis and oxidation. GSH is the precursor of phytochelatins, cysteine-rich peptides, synthesized via phytochelatin synthase (Cobbett and Goldsbrough 2002). A severe depletion of GSH is a common response to $\mathrm{Cd}$ caused by an increased consumption of GSH for phytochelatin production (Schützendübel and Polle 2002). Thus, the sharp decline in $\mathrm{GSH}$ content in $\mathrm{CdCl}_{2}$-treated rice leaves may also be due to phytochelatin biosynthesis.

The present results indicated that Spd and Spm reduced Cd-decreased ASC and GSH contents (Fig. 8). Theses observations suggest that the capacity of Spd and Spm to scavenge $\mathrm{H}_{2} \mathrm{O}_{2}$ might 

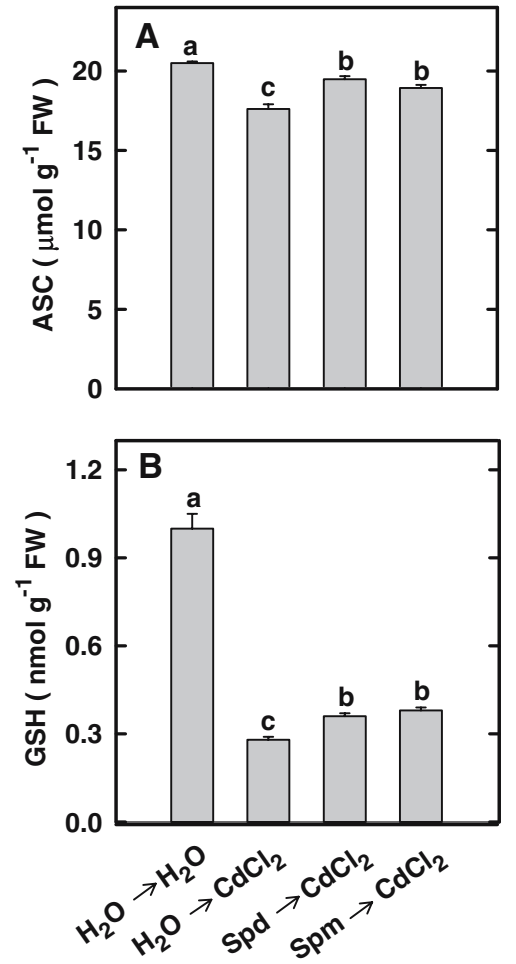

Fig. 8 Effect of pretreatments with Spd and Spm on the contents of ASC (A) and GSH (B) in detached rice leaves in the presence or absence of $\mathrm{CdCl}_{2}$. Detached rice leaves were pretreated with $\mathrm{H}_{2} \mathrm{O}, 5 \mathrm{mM} \mathrm{Spd}$, and $5 \mathrm{mM} \mathrm{Spm}$, respectively, for $6 \mathrm{~h}$ in the dark and then treated with $\mathrm{H}_{2} \mathrm{O}$ or $5 \mathrm{mM} \mathrm{CdCl}_{2}$ for $18 \mathrm{~h}$ in the light. Values with the same letter are not significantly different at $P<0.05$

Table 1 Effect of polyamines on the contents of endogenous polyamines in detached rice leaves

\begin{tabular}{llcl}
\hline Treatment & $\begin{array}{l}\text { Put }\left(\mathrm{nmol} \mathrm{g}^{-1}\right. \\
\text { FW) }\end{array}$ & $\begin{array}{l}\text { Spd }\left(\mathrm{nmol} \mathrm{g}^{-1}\right. \\
\text { FW) }\end{array}$ & \multicolumn{2}{l}{ Spm $\left(\mathrm{nmol} \mathrm{g}^{-1}\right.$} \\
\hline $\mathrm{H}_{2} \mathrm{O}$ & $182.9 \pm 9.6^{\mathrm{b}}$ & $121.83 \pm 6.6^{\mathrm{b}}$ & $89.9 \pm 8.9^{\mathrm{c}}$ \\
$\mathrm{Put}$ & $222.8 \pm 3.0^{\mathrm{a}}$ & $142.8 \pm 7.0^{\mathrm{b}}$ & $74.1 \pm 2.2^{\mathrm{c}}$ \\
$\mathrm{Spd}$ & $149.9 \pm 5.8^{\mathrm{c}}$ & $168.91 \pm 5.5^{\mathrm{a}}$ & $184.1 \pm 15.1^{\mathrm{b}}$ \\
$\mathrm{Spm}$ & $145.9 \pm 13.7^{\mathrm{c}}$ & $136.38 \pm 11.5^{\mathrm{b}}$ & $341.1 \pm 33.9^{\mathrm{a}}$ \\
\hline
\end{tabular}

Detached rice leaves were treated with either water, Put, $\mathrm{Spd}$, or Spm (5 mM) for $6 \mathrm{~h}$ in dark. Values with the same letter in each column are not significantly different at $P<0.05$

increase in rice leaves that were pretreated with Spd or Spm followed by treatment of $\mathrm{CdCl}_{2}$ (Fig. 6B).

In considering a possible mechanism for the reduction of $\mathrm{Cd}$-induced oxidative damage by

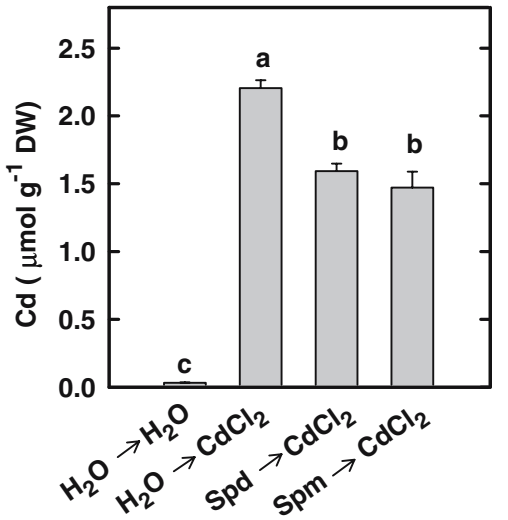

Fig. 9 Effect of pretreatments with Spd and Spm on the content of $\mathrm{Cd}$ in detached rice leaves in the presence or absence of $\mathrm{CdCl}_{2}$. Detached rice leaves were pretreated with $\mathrm{H}_{2} \mathrm{O}, 5 \mathrm{mM} \mathrm{Spd}$, and $5 \mathrm{mM}$ Spm, respectively, for $6 \mathrm{~h}$ in the dark and then treated with $\mathrm{H}_{2} \mathrm{O}$ or $5 \mathrm{mM} \mathrm{CdCl}_{2}$ for $18 \mathrm{~h}$ in the light. Values with the same letter are not significantly different at $P<0.05$

polyamines, we speculated that Spd and Spm might inhibit $\mathrm{Cd}$ uptake from the medium. Here, we show that $\mathrm{Cd}$ content in detached rice leaves pretreated with Spd and Spm followed by treatment of $\mathrm{CdCl}_{2}$ was lower that those pretreated with $\mathrm{H}_{2} \mathrm{O}$. Our findings suggest that increase in endogenous Spd or Spm may block, though slightly (27\%), the uptake of Cd (Fig. 9). In the present study, pretreatment of detached rice leaves with exogenous Spd or Spm was found to reverse almost completely the Cd-induced $\mathrm{H}_{2} \mathrm{O}_{2}$ generation and lipid peroxidation (Fig. 6). It appears that Spd and Spm were able to protect Cd-induced oxidative damage and this protection was related to the avoidance of $\mathrm{H}_{2} \mathrm{O}_{2}$ generation and the reduction of Cd uptake.

Acknowledgements This work was supported by a research grant from the National Science Council of the Republic of China (NSC 95-2313-B002-007).

\section{References}

Apel K, Hirt H (2004) Reactive oxygen species: metabolism, oxidative stress, and signal transduction. Annu Rev Plant Biol 85:235-241

Asada K (1999) The water-water cycle in chloroplasts: scavenging of reactive oxygen and dissipation of excess photons. Annu Rev Plant Physiol Plant Mol Biol 50:501-639 
Benavides MP, Gallego SM, Comga MZ, Tomaro ML (2000) Relationship between polyamines and paraquat toxicity in sunflower leaf discs. Plant Growth Regul 31:215-224

Borrell A, Carbonell L, Farrás R, Puig-Paellada P, Tiburcio AF (1997) Polyamines inhibit lipid peroxidation in senescing oat leaves. Physiol Plant 99:385390

Bors W, Langebartels C, Michel C, Sandermann H (1989) Polyamines as radical scavengers and protectants against ozone damage. Phytochemistry 28:1589-1595

Bouchereau A, Aziz A, Martin-Tanguy J (1999) Polyamines and environmental challenges: recent development. Plant Sci 140:103-125

Bradford MM (1976) A rapid and sensitive method for the quantitation of microgram quantities of protein utilizing the principle of protein-dye binding. Anal Biochem 72:248-254

Chang CJ, Kao CH (1997) Paraquat toxicity is reduced by polyamines in rice leaves. Plant Growth Regul 22:163-168

Chaoui A, Mazhoudi S, Ghorbal MH, Ferjani EE (1997) Cadmium and zinc induction of lipid peroxidation and effects on antioxidant enzyme activities in bean (Phaseolus vulgaris L.). Plant Sci 127:139-147

Chen CT, Kao CH (1991) Senescence of rice leaves. XXX. Levels of endogenous polyamines and dark-induced senescence of rice leaves. Plant Cell Physiol 32:935-941

Chen SL, Kao CH (1995) Cd induced changes in proline level and peroxidase activity in roots of rice seedlings. Plant Growth Regul 17:67-71

Chien HF, Kao CH (2000) Accumulation of ammonium in rice leaves in response to excess cadmium. Plant Sci 156:111-115

Chien HF, Lin CC, Wang JW, Chen CT, Kao CH (2002) Changes in ammonium ion content and glutamine synthetase activity in rice leaves caused by excess cadmium are a consequence of oxidative damage. Plant Growth Regul 36:41-47

Cobbett C, Goldsbrough P (2002) Phytochelatins and metallothioneins: roles in heavy metal detoxification and homeostasis. Annu Rev Plant Biol 53:159-182

Das P, Sammantaray S, Rout GR (1997) Studies on cadmium toxicity: a review. Environ Pollut 98:29-36

Dixit V, Pandey V, Shyam R (2001) Differential antioxidative responses to cadmium in roots and leaves of pea (Pisum sativum L. cv. Azad). J Exp Bot 52:11011109

Drolet G, Dumbroff EB, Legge RL, Thompson JE (1986) Radical scavenging properties of polyamines. Phytochemistry 25:367-371

Foster JG, Hess JL (1980) Response of superoxide dismutase and glutathione reductase activities in cotton leaf tissue exposed to an atmosphere enriched in oxygen. Plant Physiol 66:482-487

Foyer CH, Descourvies P, Kunert KJ (1994) Protection against oxygen radicals: an important defense mechanism studies in transgenic plants. Plant Cell Environ 17:507-523

Foyer CH, Lopez-Delgado H, Dat JF, Scott IM (1997) Hydrogen peroxide- and glutathione-associated mechanisms of acclamatory stress tolerance and signaling. Physiol Plant 100:241-254

Foyer CH, Noctor G (2005) Oxidant and antioxidant signaling in plants: re-evaluation of the concept of oxidative stress in a physiological context. Plant Cell Environ 28:1056-1071

Gallego SM, Benavides MP, Tomaro ML (1996) Effect of heavy metal ion excess on sunflower leaves: evidence for involvement of oxidative stress. Plant Sci 121:151159

Groppa MD, Tomaro ML, Benavides MP (2001) Polyamines as protectors against cadmium or copper-induced oxidative damage in sunflower leaf discs. Plant Sci 161:481-488

Heath RL, Packer L (1968) Photoperoxidation in isolated chloroplasts I. Kinetics and stoichiometry of fatty acid peroxidation. Arch Biochem Biophys 125:189-198

Hou SM, Kao CH (1993) Characteristics of the induction of the ethylene by cadmium in detached rice leaves. Bot Bull Acad Sin 34:163-168

Hsu YT, Kao CH (2003) Role of abscisic acid in cadmium tolerance of rice (Oryza sativa L.) seedlings. Plant Cell Environ 26:867-874

Hsu YT, Kao CH (2005) Abscisic acid accumulation and cadmium tolerance in rice seedlings. Physiol Plant 124:71-80

Innelli MA, Pietrni R, Fiore L, Petrilli L, Massacci A (2002) Antioxidant response to cadmium in Phragmites anstrals plants. Plant Physiol Biochem 40:977-982

Jana S, Choudhuri MA (1982) Glycolate metabolism of three submerged aquatic angiosperms during aging. Aquat Bot 12:345-354

Kato M, Shimizu S (1987) Chlorophyll metabolism in higher plants VII. Chlorophyll degradation in senescing tobacco leaves: phenolic-dependent peroxidative degradation. Can J Bot 65:729-735

Krupa Z (1988) Cadmium-induced changes in the composition and structure of the light-harvesting chlorophyll $a / b$ protein complex II in radish cotyledons. Physiol Plant 73:518-524

Kuo MC, Kao CH (2004) Antioxidant enzyme activities are upregulated in response to cadmium in sensitive, but not in tolerant rice (Oryza sativa L.) seedlings. Bot Bull Acad Sin 45:291-299

Kurepa J, Smalle J, Van Montagu M, Inzé D (1998) Polyamines and paraquat toxicity in Arabidopsis thaliana. Plant Cell Physiol 39:987-992

Larsson EH, Bordman JF, Asp H (1998) Influence of UV$\mathrm{B}$ radiation and $\mathrm{Cd}^{2+}$ on chlorophyll fluorescence, growth and nutrient content in Brassica napus. J Exp Bot 49:1031-1039

León AM, Palma JM, Corpas FJ, Gomez M, Romeropuertas MC, Chatterjee D, Mateos RM, del Rio LA, Sandalio LM (2002) Antioxidative enzymes in cultivars of pepper plants with different sensitivity to cadmium. Plant Phsyiol Biochem 40:813-820

Li C-Z, Wang G-X (2004) Interaction between reactive oxygen species, ethylene and polyamines in leaves of Glycyrrhiza inflata seedlings under root osmotic stress. Plant Growth Regul 42:55-60 
Lozano-Rodriguez E, Hernández LE, Bonay P, CarpenaRuiz R (1997) Distribution of cadmium in shoot and root tissues of maize and pea plants: physiological disturbances. J Exp Bot 48:123-128

MacAdam JW, Nelson CJ, Sharpe RE (1992) Peroxidase activity in the leaf elongation zone of tall fescue. Plant Physiol 99:872-878

Minton KW, Tabor H, Tabor CW (1990) Paraquat toxicity is increased in Escherichia coli defective in the synthesis of polyamines. Proc Natl Acad Sci USA 87:2851-2855

Nakano Y, Asda K (1981) Hydrogen peroxide is scavenged by ascorbate-specific peroxidase in spinach chloroplasts. Plant Cell Physiol 22:807-880

Noctor G, Foyer CH (1998) Ascorbate and glutathione: keeping active oxygen under control. Annu Rev Plant Physiol Plant Mol Biol 49:249-279

Olmos EO, Martínez-Solano JR, Piqueras A, Hellín E (2003) Early steps in the oxidative burst induced by cadmium in cultured tobacco cells (BY-2 line). J Exp Bot 54:291-301

Ormrod DP, Beckerson DW (1986) Polyamines as antiozonants for tomato. HortScience 21:1070-1071

Orozco-Cárdenas ML, Ryan CA (1999) Hydrogen peroxide is generated systematically in plant leaves by wounding and systemin via the octadecanoid pathway. Proc Natl Acad Sci USA 96:6553-6557

Orozco-Cárdenas M, Narváez-Vásquez J, Ryan CA (2001) Hydrogen peroxide acts as a second messenger for the induction of defense genes in tomato plants in response to wounding, systemin, and methyl jasmonate. Plant Cell 13:179-191

Paoletti F, Aldinucci D, Mocali A, Capparini A (1986) A sensitive spectrophotometric method for the determination of superoxide dismutase activity in tissue extracts. Anal Biochem 154:536-541

Piqueras A, Olmos E, Martínez-Solano JR, Hellín E (1999) Cd induced oxidative burst in tobacco BY-2 cell: time-course, subcellular location and antioxidant response. Free Radical Res 31:S25-S31

Romero-Puertas MC, Rodriguez-Serrano M, Corpas FJ, Gómez M, del Rio LA, Sandalio LM (2004) Cadmium-induced subcellular accumulation of $\mathrm{O}_{2}$ and $\mathrm{H}_{2} \mathrm{O}_{2}$ in pea leaves. Plant Cell Environ 27:11221134

Romero-Puertas MC, Zablza A, Rodriguez-Serrano M, Gómez M, del Rio LA, Sandalio LM (2003) Antioxidative response to cadmium in pea roots. Free Radical Res 37:44

Sandalio LM, Dalurzo HC, Gómez M, Romero-Puertas MC, del Rio LA (2001) Cadmium-induced changes in the growth and oxidative metabolism of pea plant. $\mathrm{J}$ Exp Bot 52:2115-2126
Schützendübel A, Polle A (2002) Plant responses to biotic stresses: heavy metal-induced oxidative stress and protection by mycorrhization. J Exp Bot 53:1351-1366

Schützendübel A, Schwang P, Teichmann T, Gross K, Langenfeld-Heyer R, Godbold DL, Polle A (2001) Cadmium-induced changes in antioxidative systems, hydrogen peroxide content, and differentiation in scots pine roots. Plant Physiol 127:887-898

Shah K, Kumar RG, Verma S, Dubey RS (2001) Effect of cadmium on lipid peroxidation, superoxide anion generation and activities of antioxidant enzymes in growing rice seedlings. Plant Sci 161:1135-1144

Sharma SS, Dietz K-J (2006) The significance of amino acids and amino acid-derived molecules in plant response and adaptation to heavy metal stress. J Exp Bot 57:711-726

Shaw BP (1995) Effect of mercury and cadmium on the activities of antioxidative enzymes in the seedlings of Phaseolus aureus. Biol Plant 37:587-596

Siedlecka A, Baszynski T (1993) Inhibition of electron flow around photosystem I in chloroplasts of cadmium-treated maize plants is due to cadmiuminduced iron deficiency. Physiol Plant 87:199-202

Slocum RD, Kaur-Sawhney R, Galston AW (1984) The physiology and biochemistry of polyamines in plants. Arch Biochem Biophys 235:283-303

Stobart AK, Griffiths WT, Ameen-Bukhari I, Sherwood RP (1985) The effect of $\mathrm{Cd}^{2+}$ on the biosynthesis of chlorophyll of barley. Physiol Plant 63:293-298

Tang W, Newton RJ, Outhavong V (2004) Exogenously added polyamines recover browning tissues into normal callus cultures and improve plant regeneration in pine. Physiol Plant 122:386-395

Thompson JE, Legge RL, Barber RF (1987) The role of free radicals in senescence and wounding. New Phytol 105:317-344

Velikova V, Yordanov I, Edreva A (2000) Oxidative stress and some antioxidant systems in acid rain-treated bean plants. Protective role of exogenous polyamines. Plant Sci 151:59-66

Wagner GJ (1993) Accumulation of cadmium in crop plants and its consequences to human health. Adv Agron 5:173-212

Wallace HM, Fraser AV, Hughes A (2003) A perspective of polyamines metabolism. Biochem J 376:1-14

Weinstein LH, Kaur-Sawhney R, Rajam MV, Wettlaufer SH, Galston AW (1986) Cadmium-induced accumulation of putrescine in oat and bean leaves. Plant Physiol 82:641-645

Yu YB, Yang SF (1980) Biosynthesis of wound ethylene. Plant Physiol 66:281-285 